\title{
OPIEKA NAD KOBIETĄ W CIAZŻY OBUMARŁEJ
}

\section{TAKING CARE OF A WOMAN DURING GRAVIDITAS OBSOLETA}

\author{
Margareta Błażej ${ }^{1}$, Katarzyna Plagens-Rotman², Maria Połocka-Molińska ${ }^{2}$ \\ ${ }^{1}$ absolwentka Uniwersytetu Medycznego im. Karola Marcinkowskiego w Poznaniu \\ ${ }^{2}$ Zakład Praktycznej Nauki Położnictwa, Katedra Zdrowia Matki i Dziecka \\ Uniwersytet Medyczny im. Karola Marcinkowskiego w Poznaniu
}

DOI: https://doi.org/10.20883/pielpol.2018.25

\begin{abstract}
STRESZCZENIE
Ciąża obumarła jest jednym z najtragiczniejszych i najbardziej traumatycznych przeżyć, jakie mogą doświadczyć rodzice. Można ją zdefiniować jako zgon płodu w organizmie matki bez względu na czas trwania ciąży, a przyczyny tego niepowodzenia mają podłoże wieloczynnikowe.

Rolą personelu medycznego jest wdrożenie właściwego postępowania diagnostyczno-leczniczego oraz udzielenie kobiecie wsparcia na najwcześniejszym etapie żałoby. Oprócz powikłań medycznych ciąża obumarła pozostawia również trwałe ślady w psychice osieroconej matki. Bardzo łatwo jest zranić niedoszłych rodziców, dlatego niezwykle istotną rolę odgrywa właściwe dobieranie słów i zindywidualizowanie podejścia do pacjentki po stracie dziecka - biorąc pod uwage jej potrzeby i stan emocjonalny. Traktowanie niedoszłej matki i jej zmarłego dziecka z szacunkiem, wyrażenie chęci rozmowy, zapewnienie jej kontaktu z psychologiem oraz umożliwienie kontaktu ze zmarłym dzieckiem dają kobiecie poczucie bezpieczeństwa, a także zmniejszają lęk i poczucie żalu po stracie dziecka.
\end{abstract}

SŁOWA KLUCZOWE: ciąża obumarła, śmierć dziecka, obumarcie płodu, strata.

\section{Wprowadzenie}

Ciąża obumarła jest jednym z najtragiczniejszych przypadków współczesnego położnictwa. Rodzice nienarodzonego jeszcze dziecka z niecierpliwością wyczekują jego przyjścia na świat. Z radością uczęszczają na rutynowe wizyty, aby choć przez chwilę móc nacieszyć się widokiem swojego maleństwa, posłuchać bicia jego serca, które jest najwspanialszą melodią dla uszu kochających rodziców. Mają możliwość podziwiać, jak ich dziecko się rozwija, przyzwyczajają się do myśli, że już niedługo przyjdzie im sprawdzić się w najpiękniejszej roli na świecie - roli rodzica. Tworzą swój wspaniały świat, pełen miłości i szczęścia, oczekując na najwspanialszy dzień w ich życiu, dzień, w którym wszystko ma ulec zmianie, a całe ich życie się przewartościuje.

Ciąża obumarła jest problemem niezwykle delikatnym oraz złożonym, w przebiegu którego mamy do czy-

\section{ABSTRACT}

Graviditas obsoleta is the most tragic and traumatic experience that parents can live through. You can define it as death of the fetus in the mother's organism without regard to duration of pregnancy and its causes might be multifactorial.

The staff's role is to implement the appropriate way of diagnosis and to support the woman in the time of mourning. Besides the medical complications, the graviditas obsolete leaves permanent marks in the mother's psyche. It is very easy to hurt the would-be parents and it is crucial to choose words wisely and to individualize the treatment of the patient on her needs and emotional state. Treating the would - be mother and her dead child with respect, expressing the will to talk, supporting her with the psychological assistance and permitting the patient to contact the dead body assure a sense of security and what is more, decrease the anxiety and the sense of regret after the loss of the child.

KEYWORDS: graviditas obsolete, death of the child, fetal death, loss.

nienia nie tylko z powikłaniami natury medycznej, ale również psychicznej - jedne i drugie stanowią obecnie ważny problem w położnictwie [1-3]. Istotą tego problemu są trudności wynikające z ustalenia jednej wyraźnej przyczyny, gdyż posiadają one wieloczynnikowe podłoże [4]. Częściej jednak można spotkać się z bagatelizowaniem tych drugich. Obecnie wiadomo, iż ból po stracie dziecka nie jest wprost proporcjonalny do czasu trwania ciąży, lecz zależy od rodzaju więzi, która wytwarza się między matką a dzieckiem od chwili poczęcia [5], zatem niedoszli rodzice wymagają wsparcia psychologicznego [1].

Obumarciem płodu określamy zgon płodu, następujący przed jego całkowitym wydaleniem bądź wydobyciem z organizmu matki, bez względu na długość trwania ciąży [6], przy czym ciąża, której koniec nastąpił przed 22. tygodniem, nosi miano poronienia. Wewnątrzmaciczne obumarcie płodu dzieli się na: 
- $\quad$ wczesne - obumarcie płodu poniżej 20. tygodnia ciąży,

- $\quad$ pośrednie - obumarcie płodu między 20. a 27. tygodniem ciąży,

- $\quad$ późne - obumarcie płodu powyżej 27. tygodnia ciąży [7].

O bólu po stracie dziecka nie decydują jednak tylko liczby - dla niedoszłych rodziców nie ma znaczenia, czy dziecko obumarło w 12. czy 32. tygodniu ciąży, przeżywają oni stratę zawsze tak samo mocno, lecz każdy na swój sposób. Z punktu widzenia personelu medycznego najważniejsze jest dostosowanie postępowania do zindywidualizowanych potrzeb każdego z rodziców i wsparcie na każdym etapie wewnątrzmacicznego obumarcia płodu [1].

Rodzice po stracie dziecka wymagają opieki wyjątkowej, która powinna zostać udzielona już w początkowym etapie tego tragicznego zdarzenia - począwszy od zdiagnozowania ciąży obumarłej, przez poprowadzenie porodu, aż do odzyskania przez osieroconych rodziców zdolności do ponownego funkcjonowania w codziennym życiu. Taka tragedia na zawsze pozostawi w ich pamięci trwały ślad, dlatego jakość opieki sprawowanej nad kobietą w ciąży obumarłej jest niezwykle istotna dla jej zdrowia fizycznego oraz psychicznego. Nikt nie potrafi sobie wyobrazić, co czują rodzice po stracie dziecka oprócz nich samych. Często ich ból wpływa na zachowanie innych ludzi, którzy nie wiedzą, jak w takiej sytuacji postępować i jak udzielić im wsparcia, aby ich nie urazić. Właśnie dlatego temat ten jest tak poważny, istotny i delikatny. Co mogą czuć rodzice po największej tragedii, jaka mogła im się przydarzyć? Jak powinna wyglądać opieka nad kobietą w ciąży obumarłej? W jaki sposób udzielić wsparcia osieroconym rodzicom, aby nie sprawić im jeszcze większego bólu? „... W jaki sposób opiekować się kobietą po poronieniu, aby zapobiec późniejszym konsekwencjom w życiu i funkcjonowaniu samych kobiet (...)?" [8].

\section{Rola położnej w opiece nad ciężarną w ciąży obumarłej}

Personel medyczny powinien zapewnić pacjentce będącej w ciąży obumarłej udzielenie szczególnej pomocy. W procesie pielęgnowania niezwykle ważną rolę odgrywa położna, która wspiera osieroconych rodziców na bardzo wczesnym etapie żałoby. Rodzicami w tym czasie często targają takie emocje jak złość, poczucie winy, zaprzeczenie. Ważne jest, aby personel medyczny w tej sytuacji nie odpowiadał również złością, a wykazał wrażliwość na zaistniałą sytuację i odnosił się z szacunkiem zarówno do matki, jak i do jej zmarłego dziecka [1].
Zachowanie personelu medycznego w obliczu śmierci dziecka oraz sposób przekazywania informacji bardzo wpływają na dalsze funkcjonowanie matki - tak psychiczne, jak i fizyczne. Okazanie rodzicom wsparcia w tym okresie, rozmowa, umożliwienie im pożegnania się z dzieckiem, a nawet zwykły dotyk mówiący ,jestem tu, by Cię wspierać”, działają na rodziców w sposób terapeutyczny i pomagają im przejść przez żałobę. Należy pamiętać, że zachowanie pracowników szpitala, każdy gest, a nawet poszczególne słowa w obliczu takiej tragedii dla rodziców bardzo zyskują na sile i są przez nich doskonale zapamiętywane na bardzo długi czas i wspominane przez wiele lat. Jakość opieki nad kobietą w ciąży obumarłej może wpływać na jej stan psychiczny nawet kilka lat po porodzie martwego dziecka, dlatego ważne jest przestrzeganie określonych zasad postępowania wobec takiej pacjentki i opiekowanie się nią w sposób szczególny [9].

Kluczowym aspektem opieki nad ciężarną w ciąży obumarłej jest nawiązanie z nią dobrego kontaktu i wzbudzenie jej zaufania. W tym celu należy przy pierwszym kontakcie przedstawić się pacjentce i wyjaśnić swoją rolę $w$ opiece nad nią, udzielać odpowiedzi na wszelkie zadawane pytania oraz szczegółowo informować o stanie jej zdrowia, pamiętając, aby zachować odpowiedni ton rozmowy, a także uwzględnić jej potrzeby i oczekiwania. Pacjentce należy uświadomić, iż ma ona prawo do podejmowania własnych, świadomych decyzji w zakresie niezbędnego postępowania diagnostyczno-terapeutycznego. Wszelkie zabiegi bądź badania należy wykonywać z poszanowaniem intymności i godności kobiety, uprzednio każdorazowo uzyskując zgodę na ich wykonanie [10].

\section{Opieka położnej podczas porodu martwego dziecka}

Rodząca, która ma urodzić martwe dziecko, jest bardzo rozchwiana psychicznie i na każdy bodziec z zewnątrz może reagować bardzo emocjonalnie, dlatego na oddziale szpitalnym absolutnie nie powinna ona znajdować się w sali z innymi kobietami ciężarnymi bądź położnicami z dziećmi. Kontakt z takim środowiskiem jeszcze bardziej potęguje w kobiecie smutek i ból po stracie dziecka [10]. Oprócz umożliwienia kobiecie leżenia w odosobnieniu, położna powinna również zwrócić uwagę na odizolowanie jej od dźwięków wydawanych przez inne rodzące oraz płaczące, żywo urodzone noworodki [11]. Podczas porodu oraz bezpośrednio przed nim w trakcie hospitalizacji pacjentki z postawioną diagnozą ciąży obumarłej monitorowanie czynności serca płodu jest zbędne, gdyż nieustannie przypomina kobiecie o nieżyjącym już maleństwie, którego serce dawno już przestało bić [1]. 
W trakcie porodu martwego dziecka niezmiernie istotne jest zastosowanie środków znieczulających i to w większych ilościach niż podawane kobietom rodzącym żywe dziecko, mając jednak na uwadze, iż każda kobieta odczuwa ból inaczej - należy zatem dostosować ilość podawanych leków przeciwbólowych do subiektywnych odczuć poszczególnych pacjentek. Dolegliwości bólowe oraz zmęczenie fizyczne może również potęgować brak sprężystości martwego płodu, co powoduje znaczne spowolnienie porodu, o czym rodzice powinni zostać poinformowani. Jeszcze przed urodzeniem dziecka położna powinna ustalić z matką, jak ma wyglądać jej pierwsze spotkanie z dzieckiem. Kobieta powinna świadomie zdecydować, czy zechce dostać je tuż po porodzie, czy nieco później, a być może będzie to dla niej zbyt trudne i w ogóle się na to nie zdecyduje [1].

Wybór rodziców należy uszanować i postąpić według ich woli - jeśli nie wyrażą chęci zobaczenia dziecka, nie należy ich do tego zmuszać, gdyż może to wpłynąć niekorzystnie na ich psychikę [11].

Poród martwego dziecka jest dla jego rodziców bardzo traumatycznym przeżyciem, dlatego wymagają oni w tym czasie specjalnej troski oraz wsparcia położnej i pozostałego personelu medycznego. Rodzice utraconego dziecka powinni przeżywać ten czas razem i wzajemnie się wspierać - ojciec przeżywa śmierć tak samo mocno jak matka, dlatego należy umożliwić im wspólne przejście przez to tragiczne wydarzenie. Zadaniem położnej jest prowadzenie porodu delikatnie, w intymnej atmosferze, z ciągłym wsparciem cierpiących rodziców, którzy powinni być przygotowani na to, że ich obumarłe dziecko mogło już ulec procesowi maceracji. Położna przyjmująca poród nie powinna się spieszyć. Narodziny tak wyjątkowego dziecka powinny być owiane aurą ciszy i spokoju, aby w ten sposób okazać szacunek jemu i jego rodzicom. Personel medyczny powinien postępować bardzo ostrożnie, aby dodatkowo nie uszkodzić skóry dziecka. Prawidłowa postawa położnej i lekarza wobec rodziców podczas porodu może złagodzić ich bolesne odczucia i pozostawić w ich pamięci pozytywny obraz tych tragicznych zdarzeń [1].

\section{Pierwsze chwile po porodzie. Kontakt matki z obumarłym dzieckiem}

Moment pierwszego kontaktu ze zmarłym dzieckiem oraz jego pożegnanie mogą wywołać w rodzicach silną traumę. W medycynie pojęcie to oznacza upośledzenie tkanek, w psychologii jednak trauma funkcjonuje jako metafora, pozwalająca zrozumieć, że tak samo jak i tkanki, uszkodzony i zraniony zostać może również umysł człowieka [9]. Śmierć dziecka bezsprzecznie predysponuje do wywołania takiego stanu zarówno u matki, jak i u ojca obumarłego dziecka, dlatego tak ważne jest ich zdanie w kwestii ich najważniejszego spotkania w życiu - spotkania z dopiero co wydanym na świat zmarłym już dzieckiem. Rodzice powinni mieć możliwość zobaczenia swojego dziecka, na które tak długo czekali, jeśli tylko tego chcą, jednak jeśli nie wyrażają takich chęci, nie powinno się ich do tego zmuszać. Ci jednak, którzy zdecydowali się spędzić czas ze swoim maleństwem, nie powinni czuć się ponaglani. Czas dla nich zatrzymał się, dlatego na pożegnanie z dzieckiem powinni mieć go tyle, aż sami uznają, że są gotowi na rozstanie z dzieckiem na zawsze [1].

Wyniki badań nie potwierdzają jednoznacznie pozytywnego wpływu możliwości spotkania matki ze zmarłym dzieckiem po porodzie. Zespół naukowców ze Szwecji [12] udowodnił, iż kobiety, które mogły spędzić z dzieckiem tyle czasu, ile potrzebowały, miały mniejsze predyspozycje do depresji niż te, które tego czasu nie otrzymały wystarczająco dużo. Jednakże badanie przeprowadzane na kobietach z Wielkiej Brytanii pokazuje, że najmniej objawów depresji wykazują kobiety, które po porodzie nie miały kontaktu ze zmarłym dzieckiem, a najwięcej - te, które nie tylko je widziały, ale również dotykały [13]. Wniosek zatem nasuwa się sam - każdą kobietę należy traktować indywidualnie i poprzez umiejętność obserwacji oraz szczerej rozmowy dostosowywać się do jej potrzeb i oczekiwań w tym smutnym i traumatycznym dla niej czasie [1].

Dla rodziców bardzo bolesny jest fakt, iż nie dane im było poznać istoty, której sami dali życie, a na przyjście której przygotowywali się psychicznie i emocjonalnie przez cały czas trwania ciąży. Dlatego też istotnym elementem procesu żałoby jest zachowanie pamiątki po dziecku - namacalnej rzeczy, która da rodzicom możliwość powrócenia do wspomnień o ich zmarłym dziecku w każdej chwili oraz będzie realnym dowodem na istnienie ich maleństwa. Obecnie w szpitalach i klinikach osieroceni rodzice mają sposobność stworzenia dla siebie takiej pamiątki. Wiele placówek posiada specjalne pamiętniki, w których można umieścić dane swojego zmarłego maleństwa, uwzględniając wybrane dla niego imię, masę urodzeniową i długość ciała, a nawet pukiel włosów dziecka. Rodzice posiadają również prawo do zrobienia dziecku zdjęcia bądź nakręcenia filmu i jeśli taka jest ich wola, nie należy się jej przeciwstawiać. W czasie, który rodzice otrzymali, aby pożegnać się z małą istotką, mają oni również okazję do tego, aby ją wykąpać oraz ubrać tak, jak sobie tego życzą. Dobrym rodzajem pamiątki jest zachowanie zapachu kojarzącego się rodzicom ze zmarłym dzieckiem. Taki zapach nie tylko doskonale przywołuje wspomnienia dzięki temu, że przechowywany jest w pamięci długotrwałej, ale również wywołuje silne emocje. Dzieje się tak za sprawą umiejscowienia w mózgu układu węchowego, któ- 
ry bezpośrednio graniczy z układem limbicznym oraz hipokampem, odpowiedzialnymi właśnie za emocje, a także ich umiejscowienie w pamięci. Takie sąsiadowanie powoduje natychmiastową odpowiedź człowieka na określony zapach, pozwalając powrócić do wspomnień oraz towarzyszących im emocji [1].

Pozostawienie śladu po dziecku może okazać się bardzo pomocne w przeżywaniu poszczególnych etapów żałoby. Może zdarzyć się, że rodzice są w ogromnym dołku emocjonalnym i nie chcą mieć pamiątki po zmarłym dziecku, gdyż boją się, że przez to odczucia związane ze stratą dziecka będą do nich wracać jak bumerang. Oczywiście nie należy zmuszać ich do tego, jednak powinno się im wytłumaczyć, że takie postępowanie pozwoli im pogodzić się ze śmiercią dziecka, nawet jeśli w tej chwili nie są na to jeszcze gotowi. Rodzice, którzy nie zdecydowali się na pozostawienie upominku po maleństwie, bardzo często żałują tego dopiero później, gdy nie ma już możliwości, aby taki drobiazg stworzyć [1].

\section{Pielęgnacja kobiety w połogu}

Po pożegnaniu się niedoszłej matki z jej dzieckiem najważniejszym aspektem jest zadbanie o jej zdrowie psychiczne. W tym celu najlepiej byłoby umieścić ją na oddziale w sali jednoosobowej, tak aby miała możliwość w spokoju wraz z ojcem dziecka opłakiwać ich ogromną stratę. Główną zasadą jednak jest położenie jej z dala od kobiet w ciąży bądź szczęśliwych matek leżących w obecności dopiero co urodzonych płaczących pociech. W pierwszych dniach po porodzie fakt ten może pogłębić depresję kobiety oraz jej wielki smutek i jest to naturalna reakcja wywołana spotkanym przez nią nieszczęściem, dlatego personel medyczny powinien okazywać jej szczególne wsparcie [1].

Z chwilą wypisania osieroconej matki ze szpitala należy poinformować ją o przebiegu połogu. Prawdopodobnie będzie ona borykać się z problemem nawału mlecznego, a następnie z samą laktacją, która również będzie oddziaływać negatywnie na jej psychikę - jej ciało wydziela mleko, aby nakarmić dziecko, którego nie miała szczęścia poznać - taka myśl jest bardzo przygnębiająca. Aby pomóc kobiecie przez to przejść, należy poinformować ją o metodach radzenia sobie z nawałem pokarmu oraz wyjaśnić, co można zrobić, aby zmniejszyć uczucie pełności w piersiach [1].

Mechanizm zdrowienia polega na umiejętności radzenia sobie z traumatycznymi wydarzeniami w codziennym życiu oraz stopniowym zanikaniu objawów depresji. Szacuje się, iż w odniesieniu do urodzenia martwego dziecka proces ten może trwać około 2 lat. Powinno się mieć ten czas na uwadze w momencie, gdy pacjentka zada pytanie o ewentualną możliwość zajścia w kolejną ciążę [9]. Należy niedoszłym rodzicom bardzo delikatnie wytłumaczyć, iż szybkie zajście w ponowną ciążę nie zagłuszy ich smutku, a może jedynie pogorszyć ich sytuację emocjonalną - bywa, że nowo narodzone dziecko przypomina o tym zmarłym i potęguje jeszcze ich smutek. Kolejne dziecko nigdy nie będzie w stanie zastąpić tego utraconego, dlatego warto, aby rodzice dali sobie czas na opłakanie ich zmarłego maleństwa i nauczyli się żyć z żalem po jego odejściu [1].

Pacjentka w sytuacji utraty dziecka powinna otrzymać od personelu medycznego informacje na temat działających grup wsparcia pomagających przejść trudny okres w ich życiu, a także informacje odnośnie pomocy psychologicznej [10]. Taka wiadomość powinna być przekazana w formie pisemnej, a umieszczenie imienia i nazwiska danej pacjentki w widocznym miejscu zwiększa skuteczność przekazu [8]. Rodziców należy także poinformować o przysługujących im prawach określonych przez ustawodawcę [10]. „Rozporządzenie Ministra Zdrowia z dnia 21 grudnia 2006 r. w sprawie rodzaju i zakresu dokumentacji medycznej w zakładach opieki zdrowotnej oraz sposobu jej przetwarzania" definiuje martwe urodzenie jako wewnątrzmaciczne obumarcie płodu przed jego wydobyciem z ustroju matki lub samoistnym wydaleniem po skończonym 22. tygodniu ciąży. Urodzenie takiego dziecka rodzice powinni zgłosić do urzędu stanu cywilnego w ciągu 3 dni, zgodnie z „Ustawą z dnia 29 września 1986 r. - Prawo o aktach stanu cywilnego". W takiej sytuacji nie sporządza się aktu zgonu, a jedynie zamieszcza się w rubryce „Uwagi” informację o tym, iż dziecko urodziło się martwe. Lekarz, położna lub zakład opieki sporządzają pisemne zgłoszenie urodzenia dziecka, co stanowi podstawę aktu urodzenia - na jego bazie wystawia się skrócony akt urodzenia dziecka, który jest jednocześnie aktem jego zgonu [2, 14].

Rodzice mogą dokonać pochówku dziecka bez względu na to, ile czasu trwała ciąża, co zostało określone w „Rozporządzeniu Ministra Zdrowia z dnia 21 grudnia 2006 r. zmieniającym rozporządzenie w sprawie postępowania ze zwłokami i szczątkami ludzkimi" [15]. Pogrzeb dziecka jest dla rodziców szczególnie ważnym wydarzeniem. Należy im zaproponować spotkanie z osobą duchowną, z którą rozmowa może dać rodzicom oczyszczenie i pozwolić im podjąć dalsze decyzje. Poza tym osoba taka może ochrzcić dziecko i nadać mu imię, czego rodzice zmarłego przeważnie sobie życzą. Ukojenie znajdują również w słowach pożegnania wypowiadanych o zmarłym maleństwie przez kapłana [1].

Kobietę należy również poinformować o tym, iż zgodnie z kodeksem pracy przysługuje jej urlop macierzyński, którego czas trwania może wynosić od 7 dni do 8 tygodni po porodzie. Podstawą udzielenia urlopu ma- 
cierzyńskiego przez pracodawcę jest okazanie przez pacjentkę aktu urodzenia. Prawo daje również ubezpieczonej kobiecie możliwość do pobierania zasiłku macierzyńskiego przez okres 8 tygodni za okazaniem skróconego odpisu aktu urodzenia dziecka. Ponadto ma ona również prawo starać się o uzyskanie zasiłku pogrzebowego, lecz tylko jeśli miałby on pokryć koszty pochówku zmarłego dziecka [2, 14].

Połóg jest to także czas, w którym lekarze mogą dokładnie przyjrzeć się przyczynie wewnątrzmacicznego obumarcia płodu. W tym celu należy z kobietą przeprowadzić ponownie wywiad rodzinny, z uwzględnieniem jej przeszłości położniczej oraz przebytych lub istniejących chorób. Taka rozmowa może być dla niej bardzo trudna, zwłaszcza że nadal znajduje się ona w szoku po porodzie, jednak szczegółowe przeprowadzenie wywiadu jest bardzo ważnym elementem ustalenia przyczyny śmierci dziecka i stanowi podstawę dla dalszego planowania rodziny. W zgłębieniu źródła śmierci płodu należy również bliżej przyjrzeć się przebiegowi obecnej ciąży: istotne mogą okazać się wiek matki, stosowanie używek w trakcie trwania ciąży czy też urazy brzucha [3]. Jednym z najskuteczniejszych sposobów ustalenia powodu zgonu dziecka jest wykonanie jego sekcji zwłok. Rodzicom może być ciężko zdecydować się na takie posunięcie i muszą oni zdawać sobie sprawę z tego, iż mimo autopsji przyczyna może nadal pozostać nieznana. Ważne jest, aby zaproponować im tę metodę diagnostyczną bardzo delikatnie, z wyjaśnieniem wszystkich nurtujących ich w tej kwestii zagadnień [1]. Ponieważ jedna z najczęstszych przyczyn wewnątrzmacicznego obumarcia płodu ma podłoże genetyczne, zasadniczym punktem odniesienie jest ustalenie jego kariotypu. Oprócz oceny pośmiertnej ciała dziecka patolog powinien także przyjrzeć się łożysku i zwrócić uwagę na ewentualne anomalie w jego budowie [3]. Położna może bardzo ułatwić patologowi pracę i okazać się bardzo pomocna w ustaleniu przyczyny śmierci dziecka. W tym celu powinna ona dokumentować wszelkie objawy, które zauważyła po urodzeniu się martwego niemowlęcia - zarówno w obrębie jego ciała, jak i na powierzchni łożyska czy pępowiny. Niewielkie zmiany mogą zostać przeoczone przez patologa, dlatego wszelkie obserwacje położnej mogą okazać się przydatne [1].

\section{Aspekt psychologiczny}

Zgłębiając tematykę ciąży obumarłej, należy bliżej przyjrzeć się aspektowi psychologicznemu, który jest nieodłącznym elementem tego przypadku. Rodzice z radością wyczekują przyjścia na świat istoty, której sami dali życie, związują się z nią emocjonalnie, przewartościowują swoje życie całkowicie, by przygotować się na powitanie swojego maleństwa. Ich miłość do dziecka jest większa niż do siebie samych, ponieważ w tym małym ciałku, które matka nosi pod sercem, zawarta jest cząstka ich samych. Informacja o śmierci dziecka jest dla rodziców wstrząsająca - zarówno dla ojca, jak i dla matki. Każdy człowiek inaczej przeżywa ból i pustkę po stracie bliskiej osoby. Różny jest też rodzaj tych emocji w odniesieniu do poszczególnych osób - inaczej przeżyjemy śmierć rodzica, inaczej dziecka, a jeszcze inaczej przyjaciela. Jednak ze wszystkich możliwych stratśmierć dzieckasiejenajwiększe spustoszenie w umyśle i pozostawia po sobie trwałe blizny [16].

W umyśle kobiety po incydencie obumarcia ciąży kłębią się myśli, że to ona jest winna zaistniałej sytuacji oraz że taka sytuacja może się powtórzyć przy kolejnej ciąży. Matka po stracie dziecka może wpaść w syndrom „niedowartościowania” - skoro nie może donosić ciąży i urodzić zdrowego dziecka, to znaczy, że jest „gorsza biologicznie” i tak też się czuje [5]. Kobieta po takim przeżyciu zmienia postrzeganie samej siebie - traci wiarę w siebie, czuje się bezwartościowa, jej postawa względem otaczającego świata jest bierna, tak jakby czas się dla niej zatrzymał. Podczas gdy kobiety po urodzeniu zdrowego dziecka odczuwają głównie pozytywne emocje, radość, dumę, podniesienie wartości kobiety jako matki, która dała życie nowemu człowiekowi - osierocone matki zmagają się głównie z gniewem, żalem, poczuciem winy oraz bezradnością, a nawet wizją samobójstwa [17].

Obumarcie płodu w łonie matki jest sytuacją, do której rodzice nie są w stanie się przygotować i zawsze odczuwają rozczarowanie i zawiedzenie. Czują się oni odsunięci od społeczeństwa, gdyż mają wrażenie, że nie spełnili roli rodzicielskiej. Dominuje w nich poczucie winy za śmierć własnego dziecka. Zastanawiają się „dlaczego?”. Dlaczego to spotkało właśnie ich? [17].

Utrata najcenniejszego dla rodziców skarbu wymaga czasu. Muszą oni pożegnać się ze swoim dzieckiem i pozwolić mu odejść, jednocześnie dając sobie czas na przeżycie żałoby. Społeczeństwo często bagatelizuje problem, jakim jest ciąża obumarła, nie dając osieroconym rodzicom możliwości opłakiwania swojego maleństwa. Bliscy bardzo często nie potrafią udzielić należytego wsparcia, a do pocieszenia używają nietaktownych zwrotów. Ludzie postronni często uważają, że skoro dziecko nie zdążyło się narodzić, to smutek po jego stracie nie jest tak silny jak po śmierci żyjącego człowieka. Tymczasem żałoba jest procesem niezbędnym do odnowy stanu psychicznego zarówno matki, jak i ojca. Należy pozwolić im opłakiwać stratę, gdyż lekceważenie ich odczuć może przyczynić się do pogłębienia bólu, a nawet powstania trwałego uszkodzenia psychicznego. Żałoba jest procesem długotrwałym, na 
który składa się wiele czynników, m.in. sposób reagowania na stres i radzenia sobie z nim, osobowość, chęć posiadania dzieci, a nawet wiara w Boga. Składa się na nią wiele następujących po sobie przeżyć, takich jak osamotnienie, poczucie winy, smutek lub niepokój [16].

Bardzo ważne jest, aby pamiętać o tym, iż oprócz matki żałobę po stracie dziecka nosi również ojciec, mimo iż to nie on nosił dziecko pod swoim sercem. Cierpi on równie mocno jak matka, tylko w inny sposób. Dlatego w tym trudnym dla partnerów okresie powinni oni być dla siebie wsparciem. Fundamentalną zasadą jest słuchanie siebie nawzajem oraz mówienie o swoich uczuciach i oczekiwaniach, gdyż bez tego mogą oni oddalić się od siebie, a rozpad związku jeszcze bardziej pogłębi ich ból po stracie dziecka [18].

Położna z racji wykonywanego zawodu jest pierwszą osobą pełniącą funkcję psychoterapeutyczną w sytuacji ciąży obumarłej. Pomoc taka opiera się na udzielaniu wsparcia psychicznego osieroconym rodzicom. Opieka położnicza to nie tylko wykonywanie procedur medycznych, ale również budowanie zaufania i więzi z pacjentką oraz dodawanie jej otuchy w trudnych chwilach. To położna jako kobieta najlepiej powinna rozumieć sytuację pacjentki oraz jej oczekiwania względem personelu medycznego i zdawać sobie sprawę z jej bezradności i bezbronności [19]. Udziela ona wsparcia na bardzo wczesnym etapie żałoby i wszystko, co powie lub zrobi, ma ogromne znaczenie dla rodziców, którzy bardzo dobrze zapamiętują chwile spędzone w szpitalu i udzieloną im w tym czasie pomoc [1].

\section{Psychoterapeutyczna rola położnej w łagodzeniu bólu po stracie dziecka}

Położna wykonuje wyjątkowy i piękny zawód. To osoba będąca przy kobiecie w najważniejszych momentach jej życia. Jednym z takich momentów jest powitanie na świecie nowego człowieka. Okres wyczekiwania na pojawienie się dziecka obfituje w wiele lęków i obaw, jednak to radosny czas dla rodziców. Nie wszystkim jednak jest dane, aby przeżyć to szczęście. Śmierć dziecka to szczególnie trudne i traumatyczne wydarzenie, w którym położna również bierze udział i ma okazję jako pierwsza udzielić rodzicom niezbędnej pomocy i wsparcia w tym dla nich pełnym bólu okresie [19].

Bardzo często obserwuje się zjawisko bagatelizowania przez personel medyczny psychologicznego aspektu śmierci dziecka. Głównym powodem takiego zachowania jest nadmiar obowiązków ciążący na położnych oraz zbyt wiele pacjentek pod ich opieką. Taka specyfika pracy nie pozwala im na poświęcenie każdej pacjentce tyle czasu, ile ona potrzebuje, również pacjentce po stracie dziecka, która wymaga specjalistycznej opieki. W tak wstrząsającej sytuacji, jaką jest śmierć dziecka, również sam personel medyczny zostaje narażony na traumę, odbierając to wydarzenie jako osobiste niepowodzenie zawodowe. W celu ułatwienia pracownikom służby zdrowia radzenia sobie w takich sytuacjach dyrekcja szpitala powinna zapewnić im odbycie specjalnego szkolenia uczącego współpracy z pacjentem po stracie dziecka oraz umiejętności indywidualnego podejścia do pacjenta z racji tego, iż każda kobieta przeżywa śmierć swojego maleństwa inaczej. Bardzo ważne jest również organizowanie spotkań, w trakcie których położne miałyby możliwość wyrażenia własnych odczuć i emocji związanych z opieką nad taką pacjentką - dzięki takiej rozmowie położne miałyby możliwość zrzucenia z własnych barków ciążącego na nich balastu psychicznego przeżytego niepowodzenia [16]. Mimo jednak cennego wsparcia, jakiego udzielają im w tym czasie współpracownicy, istotna okazuje się być także rozmowa z psychologiem, która może być dla nich oczyszczająca. Bardzo ciężko jest przejść od pacjentki, która dopiero co urodziła martwe dziecko, do takiej, która z niecierpliwością i radością oczekuje przyjścia na świat zdrowego dziecka. Dlatego ważne jest, aby podczas takiej właśnie rozmowy z psychologiem dać upust własnym emocjom i nabrać sił przed podjęciem opieki nad kolejną pacjentką [1].

Sposób podejścia do pacjentki po stracie dziecka ma swoje długofalowe skutki, dlatego też niezwykle istotne jest zachowanie personelu medycznego w takich sytuacjach, gdyż wpływa on na długość oraz poziom nasilenia żałoby [8]. Rozmowa o śmierci dziecka jest niewątpliwie jedną z trudniejszych do przeprowadzenia, jednak położna powinna stworzyć kobiecie warunki do wyrażenia swoich uczuć. Bardzo ważne jest wyrażenie chęci rozmowy na ten temat oraz wyrażenie własnego zrozumienia i wsparcia w tym trudnym dla osieroconej matki czasie. Rozmowa o zmarłym dziecku bardzo często okazuje się być kojąca dla rodziców, dlatego warto poświęcić im czas i pozwolić dać upust emocjom [16].

Momentem, w którym mamy do czynienia z wystąpieniem u rodziców największego szoku, jest poinformowanie o śmierci dziecka [9]. Lekarz diagnozujący powinien również udzielić wyczerpujących odpowiedzi na wszystkie nurtujące rodziców obawy, co zmniejszy ich lęk i niepokój [1]. Położna pełni funkcję pewnego rodzaju łącznika między osieroconą matką a lekarzem. Jako osoba posiadająca wiedzę medyczną również powinna ona wytłumaczyć matce istotę tego wydarzenia, upewniając się, że kobieta rozumie. Położna powinna posługiwać się przede wszystkim językiem prostym, niebudzącym wątpliwości, unikając przy tym niezrozumiałej dla pacjentki terminologii medycznej oraz żargonu medycznego. W przypadku tak strasznego zdarzenia, jakim jest śmierć dziecka, niewiele rzeczy może 
pocieszyć pogrążoną w żałobie kobietę. Jednak istnieją zachowania, które dają jej ukojenie. W tym celu należy zachęcać niedoszłą matkę do opowiadania o swoich uczuciach i lękach. Gdy płacze, to najwidoczniej czuje, że tak trzeba - położna powinna jej na to pozwolić, gdyż jest to niezbędne, aby przejść pomyślnie proces żałoby. Bardzo pomocne może się okazać wyrażenie współczucia dla tego, co się stało - kobieta czuje wtedy, że położna solidaryzuje się z jej smutkiem [16].

Rozmowa jest jednym ze sposobów przyniesienia ulgi. Personel medyczny nie powinien unikać kobiet, które straciły dziecko, gdyż naraża je tym samym na poczucie odrzucenia czy nawet poniżenia. Nie wolno ze śmierci dziecka robić tematu tabu - prawdopodobnie jest to jedyna rzecz, o jakiej niedoszli rodzice są w stanie rozmawiać, gdyż wobec takiej tragedii nie mogą oni myśleć o niczym innym. Gdy kobieta traci dziecko, otoczenie często nie wie, jak zareagować na taką tragedię. Osoby te nie wiedzą, co powiedzieć, często urywają rozmowę i szybko zmieniają temat, nie dając kobiecie szans na opowiedzenie o tym, co się stało. Czym różni się matka, która straciła swoje dziecko, od matki, która urodziła zdrowego, szczęśliwego malucha? Dlaczego kobiecie odbiera się prawo mówienia o swoim zmarłym dziecku, jakby zakładając, że ono nie istniało? Ta kobieta właśnie tego potrzebuje - potrzebuje rozmowy o swoim dziecku, chce je wspominać, opowiadać o tym, co się stało, jakie wybrała imię dla swojego nienarodzonego dziecka i jak teraz by wyglądało - może miałoby kręcone włosy po ojcu, a może zielone oczy po matce? Należy pozwolić kobiecie mówić o jej uczuciach, gdyż przynosi jej to ukojenie i daje poczucia wsparcia [7].

Mimo chęci rozmowy bardzo często personel medyczny nie potrafi dobrać odpowiednich słów, aby właściwie pocieszyć kobietę, tak aby nie zranić jej uczuć. Źle na jej samopoczucie wpływa także postawa personelu medycznego, który ma zbyt wiele obowiązków, by poświęcić jej odpowiednią ilość czasu, przez co czuje się ona odtrącona i osamotniona w swoim bólu. Najczęstszym błędem, z jakim możemy mieć do czynienia na oddziale położniczym, jest proces odhumanizowania, gdzie odczucia i stan emocjonalny pacjentki jest spychany na dalszy plan - liczą się tylko objawy kliniczne. Zamiast podejść do tematu z sercem i solidaryzować się z pogrążoną w smutku matką, personel medyczny często odcina się od tego, odgradzając się od tematu, budując mur z takich słów jak „obumarcie płodu”, „zarodek”, „embrion”, zamiast mówić o zmarłej istotce po prostu „dziecko”. Kolejnym błędem popełnianym przez pracowników szpitala jest używanie nieodpowiednich zwrotów. „Jesteście młodzi, jeszcze będziecie mieli dziecko” albo „nie martwcie się, to zdarza się wielu rodzicom” lub „niech się Pani postara zapomnieć” - takie i wiele innych zwrotów mają okazję usłyszeć osieroceni rodzice [16]. Dziecka nie da się zastąpić, zawsze będzie ono tkwiło w sercu rodziców. Nie da się także o nim zapomnieć. Gdy umierają rodzice, zawsze będziemy o nich pamiętać, gdyż rodziców ma się jedynych w swoim rodzaju, nie da się ich ot tak wyrzucić z pamięci lub zastąpić kimś innym. Tak samo jest z dzieckiem - nie da się po prostu zapomnieć o jego istnieniu, dla rodziców ono zawsze będzie ich dzieckiem - jedynym, niepowtarzalnym i niezastąpionym, nawet jeśli nie mieli oni okazji go poznać, a czas nie uleczy powstałych ran [18]. Położna jako kobieta powinna najlepiej rozumieć niedoszłą matkę i jej ból spowodowany śmiercią dziecka. Dlatego zadaniem położnej jest również pocieszenie kobiety w taki sposób, by nie spowodować jej większego cierpienia. Nikt nie jest w stanie sobie wyobrazić, co czuje kobieta po stracie dziecka - tylko ona. Dlatego położna powinna być wobec niej szczera. Wystarczy powiedzieć „mogę tylko sobie wyobrazić, co teraz Pani czuje” albo „bardzo mi przykro z powodu Pani dziecka”. Takie szczere wyznanie może i nie sprawi, że kobieta poczuje się lepiej, ale na pewno da jej poczucie wsparcia i troski ze strony położnej, co w tym tragicznym przypadku jest bardzo ważne w procesie zdrowienia [16].

Położna jako pracownik szpitala powinna także postarać się o to, aby niedoszłym rodzicom została udzielona fachowa pomoc psychologiczna. Rozmowa z fachowcem pomoże im zrozumieć proces żałoby oraz pomóc im w walce z poczuciem winy [16]. Pomocne może się także okazać skierowanie do grupy wsparcia zrzeszającej osieroconych rodziców. Kontakt z osobami, które również doświadczyły straty dziecka, jest bardzo pomocny w procesie przeżywania żałoby. Dzielenie się przeżyciami oraz emocjami towarzyszącymi stracie dziecka w takiej grupie zmniejsza poczucie odizolowania od społeczeństwa oraz wstydu związanego z poczuciem winy, a także świadomością niespełnionej roli rodzicielskiej [1].

\section{Podsumowanie}

Temat ciąży obumarłej pomimo wielu publikacji oraz badań naukowych nadal jest jednym z najtrudniejszych i najmniej poznanych zagadnień położnictwa, wokół którego wciąż krąży wiele pytań bez odpowiedzi. Problematyka tego zdarzenia polega nie tylko na aspekcie medycznym zagadnienia związanym z jego licznymi i nie do końca poznanymi przyczynami. Mówiąc o ciąży obumarłej, trzeba przede wszystkim wziąć pod uwagę psychologiczne podłoże tego problemu, które jest znacznie trudniejszym aspektem tej komplikacji położniczej i wymaga nie tylko wiedzy medycznej z tego zakresu, ale również wielu cech społecznych, którymi musi charakteryzować się personel medyczny. W tej sy- 
tuacji nie tyle liczą się wyuczone regułki i standardy postępowania, ile umiejętność współczucia, empatii, postawienia się w sytuacji drugiej osoby oraz przeżywanie z nią jej smutku, a także okazanie serca i zrozumienia rodzicom, którzy stracili swój największy skarb [8, 20].

\section{Piśmiennictwo}

1. Charles $C$, Kavanagh B. Poród martwego płodu i śmierć noworodka. W: Chapman V, Charles C (red.). Iwanowicz-Palkus GJ (red. wyd. pol.). Biblioteka położnej. Prowadzenie porodu. Warszawa: PZWL; 2011. 381-401.

2. Bień A, Gdańska P, Piechowska J, Stadnicka SK. Poronienie i ciąża obumarła $w$ aspekcie prawa - udział położnej w opiece nad pacjentką w sytuacji utraty ciąży. J Educ Health Sport. 2016; 6: 379-390.

3. The Society of Obstetricians and Gynaecologists of Canada. Zgon wewnątrzmaciczny oraz doświadczenie straty ciąży - wytyczne postępowania. Med Prakt Ginekologia Położnictwo. 2007; 4: 42-48.

4. Fiegler P, Kamiński K, Kaźmierczak W, Radzioch J, Węgrzyn P. Przyczyny, etiologia oraz współczesne metody diagnostyki i leczenia poronień. Ginekol Prakt. 2004; 12: 26-29.

5. Barczak A. Przegrane narodziny - czyli rzecz o poronieniach. Życie i Płodność. 2008; 4: 85-94.

6. Ahmed S, Czajkowski K, Malinowska-Polubiec A, Romejko-Wolniewicz E, Zaręba-Szczudlik J. Analiza czynników ryzyka zgonów wewnątrzmacicznych płodu. Perinatol Neonatol Ginekol. 2009; 2: 203-207.

7. Jaworski S. Ciąża obumarła. W: Bręborowicz GH (red.). Położnictwo i ginekologia. Tom 1. Położnictwo. Warszawa: PZWL; 2007. 146-151.

8. Łuczak-Wawrzyniak J, Czarnecka-Iwańczuk M, Bukowska A, Konofalska N. Wczesne i późne psychologiczne skutki utraty ciąży. Ginekol Pol. 2010; 81: 374-377.

9. Chrzan-Dętkoś M. Utrata dziecka w okresie okołoporodowym - dobre praktyki szpitalne w opiece nad matką. Ginekol Prakt. 2010; 2(105): 27-30.

10. Rozporządzenie Ministra Zdrowia z dnia 9 listopada 2015 r. w sprawie standardów postępowania medycznego przy udzielaniu świadczeń zdrowotnych w dziedzinie położnictwa i ginekologii z zakresu okołoporodowej opieki położniczo-ginekologicznej, sprawowanej nad kobietą w okresie ciąży, porodu, połogu, w przypadkach występowania określonych powikłań oraz opieki nad kobietą w sytuacji niepowodzeń położniczych. Dz.U. 2015, poz. 2007.

11. Late Intrauterine Fetal Death and Stillbirth. Royal Collage of Obstetricians and Gynaecologists, Guideline No. 55, 2010, https://www.rcog.org.uk/globalassets/documents/guidelines/gtg_55.pdf (data dostępu: 05.12.2016).

12. Forrest GC, Standish E, Baum JD. Support after perinatal death: A study of support and counseling after perinatal bereavement. BMJ. 1982; 25: 1475.

13. Hughes P, Turton P, Hopper E, Evans CHD. Assessment of guidelines for good practice in psychosocial care of mothers after stillbirth: A cohort study. Lancet. 2002; 360: 114.

14. Lewicka M, Pyć M, Stawarz B, Sulima M. Charakterystyka poronień i prawa przysługujące kobiecie po stracie ciąży. Rocz Pomor Akad Med w Szczecinie. 2013; 59: 123-129.

15. Bielan Z, Machaj A, Stankowska I. Psychoseksualne konsekwencje straty dziecka w okresie ciąży i porodu. Seksuolog Pol. 2010; 8: 41-46.

16. Bartnicki J, Bubiak A, Knihinicka-Mercik Z. Psychologiczne aspekty utraty dziecka w okresie prenatalny. Piel Zdr Publ. 2014; 4: 69-78.

17. Guzewicz M. Psychologiczne i społeczne konsekwencje utraty dziecka w wyniku poronienia. Civitas et Lex. 2014; 1: 15-27.

18. Zwolenkiewicz K. W otchłani śmierci, czyli jak radzić sobie po stracie dziecka. Gliwice: Wydawnictwo Złote Myśli; 2007.

19. Baranowska B, Dmoch-Gajzlerska E, Wełna AT. Psychoterapeutyczna rola położnej w wybranych sytuacjach trudnych w okresie okołoporodowym. Położ Nauka Prakt. 2010; 2: 26-30.

Oleszczuk J, Kanadys K, Pilewska-Kozak A. Krwawienia w okresie ciąży. W: Bień A (red.). Opieka nad kobietą ciężarną. Warszawa: PZWL; 2009. 271-284.

Artykuł przyjęty do redakcji: 21.10.2017

Artykuł przyjęty do publikacji: 12.02.2018

Źródło finansowania: Praca nie jest finansowana z żadnego źródła. Konflikt interesów: Autorzy deklarują brak konfliktu interesów.

Adres do korespondencji:

Katarzyna Plagens-Rotman

ul. Maksymiliana Jackowskiego 41

60-512 Poznań

tel.: 618547225

e-mail: plagens.rotman@gmail.com

Zakład Praktycznej Nauki Położnictwa

Katedra Zdrowia Matki i Dziecka

Uniwersytet Medyczny

im. Karola Marcinkowskiego w Poznaniu 